\title{
Cancer at sea: a case-control study among male Finnish seafarers
}

\author{
H Saarni, J Pentti, E Pukkala
}

Occup Environ Med 2002;59:613-619

See end of article for authors' affiliations

.....................

Correspondence to: Dr H Saarni, Finnish Institute of Occupational Health, Kiinamyllynkatu 10, FIN-20500 Turku, Finland;

heikki.saarni@occuphealth.fi

Accepted 12 March 2002

\begin{abstract}
Aims: To study the possible work related reasons for the increased incidence of many cancers among seafarers.

Methods: A case-control study, nested in a cohort of all male seafarers ( $n=30940$ ) who, according to the files of the Seamen's Pension Fund, had worked on board Finnish ships for any time during the period 1960-80. Cases of cancer of the lung, nervous system, kidney, and pancreas, leukaemia, lymphoma, and all cases histologically defined as mesotheliomas were identified from the Finnish Cancer Registry in 1967-92. The preceding numbers of years at sea in various occupational categories were collected according to the type of ship (dry cargo ship, tanker, passenger vessel, icebreaker, other vessel).

Results: The incidence for lung cancer among engine crew increased with the increase in employment time, the odds ratio (OR) after three years being $1.68(95 \% \mathrm{Cl} 1.17$ to 2.41$)$. The OR of lung cancer for deck officers was $0.42(95 \% \mathrm{Cl} 0.29$ to 0.61$)$. Deck personnel on icebreakers had a significantly increased risk of lung cancer $\geqslant 20$ years after first employment (OR $3.41,95 \% \mathrm{Cl} 1.23$ to 9.49). The OR for mesothelioma among engine crew with a latency of 20 years was $9.75(95 \% \mathrm{Cl} 1.88$ to 50.6$)$. The OR for renal cancer among deck officers after three years employment was $2.15(95 \% \mathrm{Cl} 1.14$ to 4.08), but there was no increase by employment time or by latency. A rise of OR for lymphoma was detected among deck personnel on tankers, if the employment had lasted over three years (OR 2.78, $95 \% \mathrm{Cl} 0.98$ to 7.92 ). The risk pattern for leukaemia was similar to that of lymphoma, the OR among deck personnel on tankers varying from $2.26(95 \% \mathrm{Cl} 1.01$ to 5.06$)$ to $6.86(95 \% \mathrm{Cl} 1.62$ to 28.8$)$ depending on the length of employment.

Conclusions: Results indicate that occupational exposures of deck crews on tankers add to their risk of renal cancer, leukaemia, and possibly lymphoma. Engine crews have an asbestos related risk of mesothelioma, and the engine room conditions also seem to increase risk of lung cancer.
\end{abstract}

Seafarers from the Nordic countries have been reported to have excess cancer morbidity compared with the population on shore. ${ }^{1}$ The excess was attributable to lung cancer and alcohol associated cancers. The relative risk of pleural cancer was high in all Nordic countries.

Alcohol consumption on board ship is quite common, and has a long tradition, because cheap alcohol is available on board ship. Isolated working and living conditions with restricted recreational activities on board ship during free time, together with possible boredom, encourage alcohol consumption. $^{2}$ The seafaring population smokes more than the population on shore. ${ }^{3-5}$ However, smoking and general living habits do not fully explain all increased cancer risks among seafarers..$^{6-9}$

Asbestos, which in previous years was widely used on board ship, has been suggested to increase lung cancer among seafarers. ${ }^{6}{ }^{10-12}$ Asbestos is the only known cause of malignant mesothelioma. As a result of the vibration of the ship and various repair works of asbestos containing constructions, asbestos fibres can be loosened and spread into the indoor air on board ship..$^{60-13}$

During their work on board ship, seafarers may be exposed to various other chemical and physical potentially cancer activating substances. Paints, pigments, and cutting oils needed in ship maintenance could increase the risk of bladder cancer. ${ }^{14}$ Exposure to transported substances such as benzene, petrol, styrene, and vinyl chloride during loading, unloading, and tank cleaning operations on tankers can be a possible cause of leukaemia, renal cancer, liver cancer, and bladder cancer. ${ }^{16}{ }^{15-18}$
In an earlier study, Finnish seafarers did not have an increased general cancer incidence compared with that among all Finnish men. ${ }^{19}$ However, some cancer types were over represented among the sailing population, for example, cancers related to sun exposure (standardised incidence ratio (SIR) for non-melanoma skin cancers $1.6,95 \%$ confidence interval (CI) 1.2 to 2.2 ). Excess cases were observed for mesothelioma (SIR $2.9,95 \%$ CI 1.2 to 5.6 ) but not for lung cancer. Male deck officers had an increased risk of cancer of the kidneys (SIR 2.0, 95\% CI 1.2 to 3.1 ) and male deck crew of cancer of the pancreas (SIR 2.0, 95\% CI 1.1 to 3.3). Old age brain cancer was over represented among deck officers (SIR 4.7, 95\% CI 1.5 to 10.9) and engine officers (SIR 3.9, 95\% CI 1.3 to 9.2).

The purpose of this study was to clarify the association between cancers and characteristics of the work history of the sailors in a case-control setting, nested in the cohort of Finnish seafarers mentioned above.

\section{MATERIALS AND METHODS}

All male seafarers $(\mathrm{n}=30$ 940) who had worked on board Finnish ships for any time during the period 1960-80 and who had not died before 1 January 1967 were identified from the files of the Seamen's Pension Fund, as published earlier. ${ }^{19}$ All residents of Finland since 1 January 1967 have a unique personal identifier (PID) which is used in all the main registers in

Abbreviations: $\mathrm{Cl}$, confidence interval; $\mathrm{OR}$, odds ratio; $\mathrm{PAH}$, polyaromatic hydrocarbon; PID, personal identifier; SIR, standardised incidence ratio 


\section{Main messages}

- Finnish seafarers have an excess risk of various cancers The present results indicate that some of them may be work related.

- The study indicates a significant excess of lung cancers and mesothelioma among engine room crew.

- Deck personnel on icebreakers have an increased risk of lung cancer.

- Deck personnel on tankers have an increased incidence of leukaemia and lymphoma.

\section{Policy implications}

- Although most of the earlier cancer causing risk factors have been eliminated from newer ships, older ships with apparent work related cancer risks, including asbestos, are still sailing as secondhand ships.

- There are still cancer risks even on board modern ships, attributable to, for example, PAHs in the engine room and chemical exposure.

- More attention should be paid to safe work procedures on board ships.

Finland. The search concerning work history before the year 1967 was done according to the name and the date of birth which in Finland give almost perfect match.

Follow up of cancer through the files of the population based countrywide Finnish Cancer Registry was done automatically using the PID as a key. Primary cancers diagnosed after the date of first employment registered in the Seamen's Pension Fund or on 1 January 1967, whichever was later, and registered in the Cancer Registry file by June 1995 were eligible as cases. The following six sites were studied: lung, bronchus (International Classification of Diseases, ninth revision (ICD-9) code 162), brain/nervous system (191-192), kidney (189), leukaemia (204-208), pancreas (157), and lymphoma and multiple melanoma (201-203). In addition, all histologically defined mesotheliomas were included as cases.
For each cancer case, three (for lung cancer only two) controls were randomly selected from the same seafarer cohort. The controls had to have the same year of birth and to be alive and free of the six cancer types mentioned above when the respective cancer was diagnosed.

The numbers of years at sea in various occupational categories on board ship since 1 January 1938 were collected from the computerised files of the Seamen's Pension Fund. The post on board ship was classified as follows: deck officer, engine officer, radio officer, deck crew member, engine crew member, or catering department crew member. If the occupational category was not available in this register it was searched for in the manual files of the National Board of Navigation in Finland (Seamen's Register and Shipping Register).

The work history was collected according to the type of ship (dry cargo ship, tanker, passenger vessel, icebreaker, other vessel). Information was first collected from the files of the Seamen's Pension Fund and the National Board of Navigation. If the information from these registers was insufficient, the search was continued in Lloyd's Shipping Register, the National Board of Antiquities of the Maritime Museum of Finland, The Finnish Shipowners' Association, Rettig Oy, and finally in the files of certain individuals interested in old ships as a hobby. The occupational vacancies and types of ship were traced for virtually all; only 377 of the 35934 work years could not be accounted for.

The length of service in the occupational category and on board various types of ship was calculated separately for each person. Deck and engine officers often have service years as crew members during their earlier sailing years. Thus, one person may have work years in more than one occupational category (table 1).

The connection between work history/exposure and cancer incidence was studied by odds ratios (OR). The exposure times were studied both as a dichotomic (thresholds: one day, one month, one year) and as a linear variable. The linear correlation of exposure time with cancer morbidity was statistically tested with logistic regression analysis. The analyses were performed using the LOGISTIC procedure in the SAS 6.12 program.

The results were analysed dichotomically: whether the seafarer had spent at least a given time in service on board a

\begin{tabular}{|c|c|c|c|c|}
\hline \multirow[b]{2}{*}{ Cancer } & \multirow[b]{2}{*}{$\mathrm{n}$} & \multicolumn{2}{|c|}{ Known work history } & \multirow{2}{*}{$\begin{array}{l}\begin{array}{l}\text { Unknown work } \\
\text { history }\end{array} \\
\text { Person years }\end{array}$} \\
\hline & & $\begin{array}{l}\text { Person years } \\
\text { at sea }\end{array}$ & $\begin{array}{l}\text { Years/person } \\
\text { (mean) }\end{array}$ & \\
\hline \multicolumn{5}{|l|}{ Pancreas } \\
\hline Cases & 58 & 718 & 12.4 & 11 \\
\hline Controls & 174 & 2380 & 13.7 & 13 \\
\hline \multicolumn{5}{|c|}{ Lung, bronchus } \\
\hline Cases & 299 & 3842 & 12.8 & 32 \\
\hline Controls & 598 & 8666 & 14.5 & 75 \\
\hline \multicolumn{5}{|c|}{ Mesothelioma } \\
\hline Cases & 10 & 119 & 11.9 & 0 \\
\hline Controls & 30 & 361 & 12.0 & 1 \\
\hline \multicolumn{5}{|l|}{ Kidney } \\
\hline Cases & 69 & 1030 & 14.9 & 35 \\
\hline Controls & 207 & 2764 & 13.4 & 35 \\
\hline \multicolumn{5}{|c|}{ Brain/nervous system } \\
\hline Cases & 63 & 759 & 12.0 & 11 \\
\hline Controls & 189 & 1668 & 8.8 & 19 \\
\hline \multicolumn{5}{|c|}{ Lymphoma/myeloma } \\
\hline Cases & 81 & 868 & 10.7 & 9 \\
\hline Controls & 243 & 2290 & 9.4 & 8 \\
\hline \multicolumn{5}{|l|}{ Leukaemia } \\
\hline Cases & 41 & 556 & 13.6 & 3 \\
\hline Controls & 123 & 1345 & 10.9 & 12 \\
\hline
\end{tabular}


Table 2 Odds ratios and 95\% confidence intervals for pancreatic cancer among Finnish seafarers by characteristics of the work history (latency time 10 years)

\begin{tabular}{|c|c|c|c|c|}
\hline \multirow[b]{3}{*}{ Type of exposure } & \multicolumn{4}{|c|}{ Duration of exposure } \\
\hline & \multicolumn{2}{|l|}{$\geqslant 1$ month } & \multicolumn{2}{|l|}{$\geqslant 3$ years } \\
\hline & Cases/controls & OR $(95 \% \mathrm{Cl})$ & Cases/controls & OR $(95 \% \mathrm{Cl})$ \\
\hline \multicolumn{5}{|l|}{ Occupation } \\
\hline Deck officers & $18 / 32$ & 2.00 (1.02 to 3.93 ) & $12 / 29$ & $1.30(0.62$ to 2.76$)$ \\
\hline Engine officers & $6 / 46$ & $0.32(0.13$ to 0.80$)$ & $4 / 37$ & $0.27(0.09$ to 0.81$)$ \\
\hline Radio officers & $1 / 8$ & $0.36(0.05$ to 2.97$)$ & $1 / 6$ & $0.49(0.06$ to 4.17$)$ \\
\hline Deck crew & $22 / 51$ & $1.47(0.79$ to 2.75$)$ & $14 / 27$ & $1.73(0.84$ to 3.59$)$ \\
\hline Engine crew & $12 / 50$ & 0.65 (0.32 to 1.32$)$ & $7 / 24$ & $0.86(0.35$ to 2.11$)$ \\
\hline Catering & $10 / 30$ & $1.00(0.46$ to 2.20$)$ & $1 / 16$ & $0.17(0.02$ to 1.34$)$ \\
\hline \multicolumn{5}{|l|}{ Type of ship } \\
\hline Dry cargo vessel & $45 / 139$ & 0.87 (0.42 to 1.79$)$ & $30 / 107$ & 0.67 (0.37 to 1.22$)$ \\
\hline Tanker & $23 / 78$ & 0.81 (0.44 to 1.48$)$ & $8 / 23$ & $1.05(0.44$ to 2.50$)$ \\
\hline Deck personnel* & $13 / 23$ & 1.90 (0.89 to 4.04$)$ & $5 / 6$ & 2.64 (0.78 to 9.00$)$ \\
\hline Engine personnel* & $7 / 41$ & $0.45(0.19$ to 1.06$)$ & $3 / 13$ & 0.68 (0.19 to 2.46$)$ \\
\hline Icebreaker & $5 / 7$ & 2.25 (0.69 to 7.39$)$ & $0 / 1$ & - \\
\hline Engine personnel* & $2 / 5$ & $1.21(0.23$ to 6.40$)$ & $0 / 1$ & - \\
\hline Passenger ship & $22 / 61$ & 1.13 (0.61 to 2.09$)$ & $4 / 19$ & $0.60(0.20$ to 1.86$)$ \\
\hline Other & $13 / 34$ & 1.19 (0.58 to 2.45$)$ & $2 / 7$ & 0.85 (0.17 to 4.22$)$ \\
\hline
\end{tabular}

Table 3 Odds ratios and 95\% confidence intervals for lung cancer among Finnish seafarers by characteristics of the work history (latency time 10 years)

\begin{tabular}{|c|c|c|c|c|}
\hline \multirow[b]{3}{*}{ Type of exposure } & \multicolumn{4}{|c|}{ Duration of exposure } \\
\hline & \multicolumn{2}{|l|}{$\geqslant 1$ month } & \multicolumn{2}{|l|}{$\geqslant 3$ years } \\
\hline & Cases/controls & OR $(95 \% \mathrm{CI})$ & Cases/controls & OR $(95 \% \mathrm{CI})$ \\
\hline \multicolumn{5}{|l|}{ Occupation } \\
\hline Deck officers & $43 / 170$ & $0.42(0.29$ to 0.61$)$ & $39 / 139$ & $0.50(0.34$ to 0.73$)$ \\
\hline Engine officers & $88 / 151$ & 1.24 (0.91 to 1.69$)$ & $67 / 112$ & 1.25 (0.89 to 1.76$)$ \\
\hline Radio officers & $3 / 15$ & $0.39(0.11$ to 1.37$)$ & $1 / 12$ & $0.16(0.02$ to 1.27$)$ \\
\hline Deck crew & $96 / 196$ & $0.97(0.72$ to 1.31$)$ & $45 / 91$ & 0.99 (0.67 to 1.45$)$ \\
\hline Engine crew & $97 / 170$ & $1.21(0.90$ to 1.63$)$ & $63 / 82$ & $1.68(1.17$ to 2.41$)$ \\
\hline Catering & $38 / 85$ & $0.88(0.58$ to 1.33$)$ & $16 / 43$ & $0.73(0.40$ to 1.32$)$ \\
\hline \multicolumn{5}{|l|}{ Type of ship } \\
\hline Dry cargo vessel & $242 / 509$ & 0.74 (0.52 to 1.07$)$ & $180 / 370$ & $0.93(0.70$ to 1.24$)$ \\
\hline Tanker & $149 / 281$ & 1.12 (0.85 to 1.48$)$ & $41 / 92$ & 0.87 (0.59 to 1.30 ) \\
\hline Deck personnel & $67 / 136$ & $0.98(0.70$ to 1.37$)$ & $21 / 46$ & 0.91 (0.53 to 1.55$)$ \\
\hline Engine personnel & $78 / 119$ & 1.42 (1.02 to 1.97$)$ & $18 / 37$ & 0.97 (0.54 to 1.74$)$ \\
\hline Passenger ship & $110 / 235$ & 0.90 (0.68 to 1.20$)$ & $31 / 75$ & 0.81 (0.52 to 1.26$)$ \\
\hline Icebreaker & $23 / 31$ & 1.52 (0.87 to 2.66$)$ & $5 / 5$ & 2.0210 .58 to 7.02 \\
\hline Deck personnel & $11 / 12$ & $1.87(0.81$ to 4.28$)$ & $1 / 1$ & $2.00(0.13$ to 32.1$)$ \\
\hline Engine personnel & $11 / 21$ & $1.05(0.50$ to 2.21$)$ & $4 / 4$ & $2.01(0.50$ to 8.11$)$ \\
\hline Other & $69 / 145$ & $0.94(0.68$ to 1.30$)$ & $7 / 25$ & 0.55 (0.24 to 1.29$)$ \\
\hline
\end{tabular}

certain type of ship or not, or whether he had worked in a certain post on board ship or not. The results for the cut off points of one day and one month were almost identical, and therefore only the latter ones are shown in this report. The latency time, the time between the exposure and the identification of cancer, was basically set at 10 years, but ORs for 5 and 20 year latency times were also calculated. In the analyses by type of ship, a further stratification into deck personnel (officers and crew) and engine room personnel was made to find possible interactions attributable to different exposure conditions.

It was planned that information on life habits would be collected for cases and controls. This would have been especially important for lung cancer where smoking is such a strong confounder. The vital status of the 299 cases with lung cancer on 1 July 1996 was obtained from the National Population Register Center. This register also includes information on the closest relatives and the contact information for those who have been living in the same household since 1974. Only 18 persons with lung cancer were alive. It was possible to find a living next of kin for 174 (64\%) of the deceased seafarers with lung cancer. From similar earlier studies we know that only about $50 \%$ of those asked about the smoking and other life habits of their deceased relatives answer the questions. As it would have been possible to get any information for less than one third of the cases, and taking into account the recall bias involved in this kind of survey, the planned interview was abandoned.

\section{RESULTS}

The OR between cases and controls of pancreatic cancer for deck officers was 2.00 (95\% CI 1.02 to 3.93); the OR did not, however, grow with the increase in latency time or with employment time as a deck officer (table 2). The OR for engine officers was significantly low (0.32 to 0.27 depending on the length of the exposure time). The changes in latency time had no effects on the results.

The OR of lung cancer for deck officers was 0.42 (95\% CI 0.29 to 0.61 ; table 3 ). Among engine crew, the OR of lung cancer increased with the increase in employment time; after 
Table 4 Odds ratios and 95\% confidence intervals for mesothelioma among Finnish seafarers by characteristics of the work history (latency time 10 years)

\begin{tabular}{|c|c|c|c|c|}
\hline \multirow[b]{3}{*}{ Type of exposure } & \multicolumn{4}{|c|}{ Duration of exposure } \\
\hline & \multicolumn{2}{|l|}{$\geqslant 1$ month } & \multicolumn{2}{|l|}{$\geqslant 3$ years } \\
\hline & Cases/controls & OR $(95 \% \mathrm{Cl})$ & Cases/controls & OR $(95 \% \mathrm{Cl})$ \\
\hline \multicolumn{5}{|l|}{ Occupation } \\
\hline Deck officers & $2 / 5$ & 1.25 (0.20 to 7.74$)$ & $1 / 4$ & $0.72(0.07$ to 7.34$)$ \\
\hline Engine officers & $4 / 7$ & $2.19(0.48$ to 10.0$)$ & $4 / 4$ & 4.33 (0.84 to 22.5$)$ \\
\hline Radio officers & $0 / 0$ & - & $0 / 0$ & - \\
\hline Deck crew & $3 / 11$ & $0.74(0.16$ to 3.46$)$ & $2 / 4$ & $1.63(0.25$ to 10.6$)$ \\
\hline Engine crew & $6 / 5$ & 7.50 (1.53 to 36.7$)$ & $3 / 3$ & 3.86 (0.64 to 23.4$)$ \\
\hline Catering & $0 / 10$ & & $0 / 5$ & \\
\hline \multicolumn{5}{|l|}{ Type of ship } \\
\hline Dry cargo vessel & $8 / 20$ & $2.00(0.36$ to 11.2$)$ & $3 / 13$ & $0.56(0.12$ to 2.60$)$ \\
\hline Tanker & $7 / 15$ & $2.33(0.51$ to 10.8$)$ & $2 / 5$ & $1.25(0.20$ to 7.74$)$ \\
\hline Deck personnel & $3 / 9$ & $1.00(0.21$ to 4.78$)$ & $0 / 5$ & \\
\hline Engine personnel & $5 / 6$ & 4.00 (0.87 to 18.5 & $2 / 0$ & \\
\hline Passenger ship & $3 / 12$ & 0.64 (0.14 to 2.99 ) & $0 / 7$ & - \\
\hline Icebreaker & $1 / 1$ & $3.22(0.18$ to 56.9$)$ & $1 / 0$ & - \\
\hline Other & $3 / 4$ & $2.79(0.50$ to 15.5$)$ & $1 / 0$ & - \\
\hline
\end{tabular}

Table 5 Odds ratios and 95\% confidence intervals for renal cancer among Finnish seafarers by characteristics of the work history (latency time 10 years)

\begin{tabular}{|c|c|c|c|c|}
\hline \multirow[b]{3}{*}{ Type of exposure } & \multicolumn{4}{|c|}{ Duration of exposure } \\
\hline & \multicolumn{2}{|l|}{$\geqslant 1$ month } & \multicolumn{2}{|l|}{$\geqslant 3$ years } \\
\hline & Cases/controls & OR $(95 \% \mathrm{CI})$ & Cases/controls & OR $(95 \% \mathrm{Cl})$ \\
\hline \multicolumn{5}{|l|}{ Occupation } \\
\hline Deck officers & $23 / 45$ & $1.80(0.99$ to 3.28$)$ & $20 / 33$ & 2.15 (1.14 to 4.08$)$ \\
\hline Engine officers & $19 / 52$ & $1.13(0.61$ to 2.09$)$ & $15 / 37$ & 1.28 (0.65 to 2.50$)$ \\
\hline Radio officers & $3 / 2$ & $4.66(0.76$ to 28.5$)$ & $3 / 0$ & - \\
\hline Deck crew & $24 / 75$ & $0.94(0.53$ to 1.66$)$ & $10 / 39$ & 0.73 (0.34 to 1.55$)$ \\
\hline Engine crew & $20 / 65$ & $0.89(0.49$ to 1.62$)$ & $10 / 33$ & 0.89 (0.42 to 1.92$)$ \\
\hline Catering & $7 / 37$ & $0.52(0.22$ to 1.22$)$ & $4 / 13$ & 0.92 (0.29 to 2.92$)$ \\
\hline \multicolumn{5}{|l|}{ Type of ship } \\
\hline Dry cargo vessel & $57 / 169$ & $1.07(0.52$ to 2.18$)$ & $44 / 119$ & 1.30 (0.74 to 2.29$)$ \\
\hline Tanker & $29 / 86$ & $1.02(0.59$ to 1.77$)$ & $9 / 19$ & $1.48(0.64$ to 3.45$)$ \\
\hline Deck personnel & $15 / 32$ & $1.52(0.77$ to 3.01$)$ & $4 / 4$ & $3.12(0.76$ to 12.8$)$ \\
\hline Engine personnel & $14 / 46$ & $0.89(0.46$ to 1.75$)$ & $3 / 12$ & 0.74 (0.20 to 2.70$)$ \\
\hline Passenger ship & $29 / 80$ & $1.15(0.66$ to 2.00$)$ & $9 / 19$ & $1.48(0.64$ to 3.45$)$ \\
\hline Icebreaker & $4 / 16$ & $0.74(0.24$ to 2.28$)$ & $2 / 2$ & $3.06(0.42$ to 22.1$)$ \\
\hline Deck personnel & $1 / 5$ & $0.59(0.07$ to 5.18$)$ & $0 / 2$ & - \\
\hline Engine personnel & $3 / 11$ & $0.81(0.22$ to 3.00$)$ & $2 / 0$ & - \\
\hline Other & $12 / 44$ & $0.78(0.39$ to 1.58$)$ & $2 / 4$ & $1.52(0.27$ to 8.46$)$ \\
\hline
\end{tabular}

three years it was 1.68 (95\% CI 1.17 to 2.41$)$. The OR per linear increase in 10 years was 1.22 (95\% CI 1.00 to 1.63$)$. Deck personnel who had been working more than one month on icebreakers had a significantly increased OR with latency times of one year $(2.21,95 \%$ CI 1.03 to 4.77$)$, five years $(2.22$, $95 \%$ CI 1.00 to 4.93$)$, and 20 years $(3.41,95 \%$ CI 1.23 to 9.49$)$, but not with a latency of 10 years, a priori defined as the most likely latency.

The OR in mesothelioma among engine crew was 7.50 (95\% CI 1.53 to 36.7) when a latency time of 10 years was used (table 4 ). With a latency time of 20 years, the OR increased to 9.75 ( 1.88 to 50.6). The OR also tended to be increased among engine officers.

The OR for kidney cancer among deck officers after three years employment was 2.15 (95\% CI 1.14 to 4.08 ), and there was an increase by exposure time. The OR per linear increase in 10 years was 1.34 (95\% CI 1.00 to 1.79; table 5). The OR per linear increase in 10 years exposure time among deck personnel on tankers was 11.8 (95\% CI 1.34 to 97.0 ).

The OR in brain and nervous system cancer was close to 1.0 in all categories of seafarers (table 6). A trend by exposure time was seen among engine officers. The OR per linear increase in 10 years exposure was 1.62 (95\% CI 1.00 to 2.59 ).

The only category of seafarers showing a (borderline) significant OR for lymphoma/myeloma was the deck personnel on tankers; their risk also increased with increasing time at work (table 7).

The risk pattern for leukaemia was similar to that for lymphoma, the deck personnel on tankers having an even clearer excess of leukaemia and a clearer increase with increasing exposure time. The OR per linear increase in 10 years exposure was 4.41 (95\% CI 1.00 to 20.1 ; table 8 ).

\section{DISCUSSION}

The present study concerned the eight types of cancer which have been reported to be over represented among seafarers as possible work related diseases. Cancers considered to be connected entirely with sunburn (skin melanoma) and life habits (certain alcohol related cancers) were excluded. Because most female seafarers had been working in the catering department, only male sailors were included in this study. 
Table 6 Odds ratios and 95\% confidence intervals for brain and nervous system cancer among Finnish seafarers by characteristics of the work history (latency time 10 years)

\begin{tabular}{|c|c|c|c|c|}
\hline \multirow[b]{3}{*}{ Type of exposure } & \multicolumn{4}{|c|}{ Duration of exposure } \\
\hline & \multicolumn{2}{|l|}{$\geqslant 1$ month } & \multicolumn{2}{|l|}{$\geqslant 3$ years } \\
\hline & Cases/controls & OR $(95 \% \mathrm{Cl})$ & Cases/controls & OR $(95 \% \mathrm{Cl})$ \\
\hline \multicolumn{5}{|l|}{ Occupation } \\
\hline Deck officers & $14 / 28$ & $1.64(0.80$ to 3.36$)$ & $10 / 22$ & 1.43 (0.64 to 3.22$)$ \\
\hline Engine officers & $12 / 33$ & $1.11(0.54$ to 2.31$)$ & $9 / 20$ & $1.41(0.61$ to 3.28$)$ \\
\hline Radio officers & $2 / 6$ & $1.00(0.20$ to 5.09$)$ & $1 / 3$ & $1.00(0.10$ to 9.79$)$ \\
\hline Deck crew & $20 / 67$ & 0.85 (0.46 to 1.56$)$ & $9 / 31$ & 0.85 (0.38 to 1.90$)$ \\
\hline Engine crew & $16 / 53$ & $0.87(0.46$ to 1.67$)$ & $7 / 19$ & $1.12(0.45$ to 2.80$)$ \\
\hline Catering & $16 / 52$ & $0.90(0.47$ to 1.72$)$ & $9 / 9$ & 3.33 (1.26 to 8.82 ) \\
\hline \multicolumn{5}{|l|}{ Type of ship } \\
\hline Dry cargo vessel & $47 / 137$ & 1.12 (0.58 to 2.14$)$ & $29 / 80$ & $1.16(0.66$ to 2.06$)$ \\
\hline Tanker & $28 / 74$ & $1.24(0.70$ to 2.21$)$ & $11 / 21$ & 1.69 (0.77 to 3.74$)$ \\
\hline Deck personnel & $12 / 37$ & 0.97 (0.47 to 1.99 ) & $7 / 12$ & $1.84(0.69$ to 4.9$)$ \\
\hline Engine personnel & $12 / 30$ & $1.25(0.60$ to 2.61$)$ & $3 / 7$ & $1.30(0.33$ to 5.19$)$ \\
\hline Passenger ship & $21 / 73$ & $0.80(0.44$ to 1.45$)$ & $7 / 16$ & 1.35 (0.53 to 3.45$)$ \\
\hline Icebreaker & $3 / 14$ & $0.63(0.17$ to 2.25$)$ & $1 / 4$ & 0.75 (0.08 to 6.80$)$ \\
\hline Deck personnel & $2 / 7$ & 0.85 (0.17 to 4.21$)$ & $0 / 3$ & - \\
\hline Engine personnel & $1 / 6$ & $0.49(0.06$ to 4.17$)$ & $1 / 1$ & $3.03(0.19$ to 49.20$)$ \\
\hline Other & $10 / 27$ & $1.13(0.51$ to 2.49$)$ & $2 / 1$ & $6.16(0.55$ to 69.2$)$ \\
\hline
\end{tabular}

Table 7 Odds ratios and $95 \%$ confidence intervals for lymphoma/myeloma cancer among Finnish seafarers by characteristics of the work history (latency time 10 years)

\begin{tabular}{|c|c|c|c|c|}
\hline \multirow[b]{3}{*}{ Type of exposure } & \multicolumn{4}{|c|}{ Duration of exposure } \\
\hline & \multicolumn{2}{|l|}{$\geqslant 1$ month } & \multicolumn{2}{|l|}{$\geqslant 3$ years } \\
\hline & Cases/controls & OR $(95 \% \mathrm{CI})$ & Cases/controls & OR $(95 \% \mathrm{CI})$ \\
\hline \multicolumn{5}{|l|}{ Occupation } \\
\hline Deck officers & $18 / 37$ & 1.59 (0.85 to 2.99$)$ & $14 / 31$ & $1.43(0.72$ to 2.84$)$ \\
\hline Engine officers & $11 / 47$ & $0.66(0.32$ to 1.33$)$ & $8 / 41$ & $0.54(0.24$ to 1.21$)$ \\
\hline Radio officers & $1 / 2$ & $1.51(0.14$ to 16.8$)$ & $1 / 2$ & $1.51(0.14$ to 16.8$)$ \\
\hline Deck crew & $25 / 68$ & 1.15 (0.66 to 1.99$)$ & $9 / 25$ & 1.09 (0.49 to 2.44$)$ \\
\hline Engine crew & $21 / 66$ & $0.94(0.53$ to 1.66$)$ & $11 / 24$ & $1.43(0.67$ to 3.07$)$ \\
\hline Catering & $10 / 55$ & $0.48(0.23$ to 1.00$)$ & $4 / 10$ & 1.21 (0.37 to 3.97$)$ \\
\hline \multicolumn{5}{|l|}{ Type of ship } \\
\hline Dry cargo vessel & $49 / 155$ & $0.87(0.52$ to 1.46$)$ & $38 / 100$ & $1.26(0.76$ to 2.10$)$ \\
\hline Tanker & $30 / 89$ & $1.02(0.61$ to 1.71$)$ & $10 / 20$ & $1.57(0.70$ to 3.51$)$ \\
\hline Deck personnel & $13 / 32$ & 1.26 (0.63 to 2.54$)$ & $7 / 8$ & 2.78 (0.98 to 7.92$)$ \\
\hline Engine personnel & $14 / 51$ & $0.79(0.41$ to 1.51$)$ & $3 / 11$ & 0.81 (0.22 to 2.98$)$ \\
\hline Passenger ship & $26 / 55$ & $1.62(0.93$ to 2.81$)$ & $5 / 12$ & $1.27(0.43$ to 3.71$)$ \\
\hline lcebreaker & $2 / 10$ & $0.59(0.13$ to 2.75$)$ & $0 / 3$ & - \\
\hline Other & $11 / 24$ & $1.43(0.67$ to 3.07$)$ & $3 / 5$ & $1.83(0.43$ to 7.84$)$ \\
\hline
\end{tabular}

The sailor cohort collection was unselected in terms of cancer incidence or general mortality - that is, possible later cancer diagnosis and death neither decreased nor increased the likelihood of a person being included in the cohort. ${ }^{19}$

The working history of each cancer case and the controls was clarified from the files of the Seamen's Pension Fund and from the registers of the Finnish Maritime Administration. Shipowners have been obliged to report every worker's days on board ship to this central register since 1938. These registers are used for official, legal, and insurance purposes, and also for official national statistics in the maritime industry; they are therefore very accurate. Additional details were collected from historical documents, for example, Lloyd's Shipping Register, which is one of the most reliable registers in the shipping industry. Information on some of the very old working years and the years during the Second World War were difficult to find, but less than $1 \%$ of all working histories remained unsolved.

The OR of lung cancer among engine crew increased borderline significantly with increasing years at work. This suggests that engine room conditions may include factors that add to the risk of lung cancer, such as polyaromatic hydrocarbons (PAHs) and asbestos. ${ }^{20}$ Old steamers were coal driven, and crew members shovelling coal into ovens were exposed to coal dust, combustion products, heat, and the strain of heavy physical work. Combustion products have been reported to increase the risk of pulmonary cancer. ${ }^{21}$ Unfortunately, on the basis of the information available it was not possible to analyse work on steamers separately from that on board other ships.

The risk of mesothelioma was especially high among engine crew, the OR approaching 10 after 20 years of latency. The OR was also increased among engine crew officers. Asbestos is the only known cause of malignant mesothelioma and it was widely used earlier on board ship. As a result of the vibration of the ship and various repair works of asbestos containing constructions, asbestos fibres can be loosened and spread into the indoor air on board ship. ${ }^{60-12}$ There should not be any notable dose-response between asbestos exposure and mesothelioma and we did not see such an effect. The long latency also observed in the present study is typical of the asbestos-mesothelioma relation. ${ }^{22}$ 
Table 8 Odds ratios and 95\% confidence intervals for leukaemia among Finnish seafarers by characteristics of the work history (latency time 10 years)

\begin{tabular}{|c|c|c|c|c|}
\hline \multirow[b]{3}{*}{ Type of exposure } & \multicolumn{4}{|c|}{ Duration of exposure } \\
\hline & \multicolumn{2}{|l|}{$\geqslant 1$ month } & \multicolumn{2}{|l|}{$\geqslant 3$ years } \\
\hline & Cases/controls & OR $(95 \% \mathrm{Cl})$ & Cases/controls & OR $(95 \% \mathrm{Cl})$ \\
\hline \multicolumn{5}{|l|}{ Occupation } \\
\hline Deck officers & $13 / 25$ & $1.82(0.83$ to 4.01$)$ & $10 / 21$ & $1.57(0.67$ to 3.68$)$ \\
\hline Engine officers & $11 / 25$ & $1.44(0.63$ to 3.26$)$ & $7 / 18$ & $1.20(0.46$ to 3.12$)$ \\
\hline Radio officers & $0 / 2$ & - & $0 / 2$ & - \\
\hline Deck crew & $16 / 39$ & 1.38 (0.66 to 2.87$)$ & $5 / 16$ & 0.93 (0.32 to 2.72 ) \\
\hline Engine crew & $4 / 31$ & $0.32(0.11$ to 0.97$)$ & $0 / 11$ & - \\
\hline Catering & $7 / 25$ & 0.81 (0.32 to 2.03 ) & $2 / 4$ & $1.53(0.27$ to 8.65$)$ \\
\hline \multicolumn{5}{|l|}{ Type of ship } \\
\hline Dry cargo vessel & $33 / 95$ & $1.22(0.59$ to 2.93$)$ & $22 / 61$ & 1.18 (0.58 to 2.39$)$ \\
\hline Tanker & $22 / 41$ & $2.32(1.13$ to 4.75$)$ & $6 / 12$ & $1.59(0.55$ to 4.54$)$ \\
\hline Deck personnel & $13 / 21$ & 2.26 (1.01 to 5.06 ) & $6 / 3$ & $6.86(1.63$ to 28.8$)$ \\
\hline Engine personnel & $6 / 16$ & $1.15(0.42$ to 3.16$)$ & $0 / 8$ & - \\
\hline Passenger ship & $17 / 39$ & $1.53(0.74$ to 3.16$)$ & $1 / 8$ & 0.36 (0.09 to 2.96 ) \\
\hline Icebreaker & $0 / 6$ & - & $0 / 1$ & - \\
\hline Other & $6 / 20$ & 0.88 (0.33 to 2.38 ) & $2 / 7$ & 0.85 (0.17 to 4.26$)$ \\
\hline
\end{tabular}

An increased risk of brain cancer has in some studies been associated with exposure at work, for example, with electric and magnetic field exposure. ${ }^{23} \mathrm{~A}$ fourfold risk of cancer of the brain and nervous system was found previously among Finnish deck and engine officers whose first employment was at an older age. ${ }^{19}$ However, no signs of work related risk were observed for cancers of the brain or nervous system in the present study.

The excess of kidney cancer was significantly high (twofold) among deck officers on any ship, and the point estimate was highest (threefold, although not significant) among deck crew on tankers. Exposure to the fumes of gasoline and other cargo chemicals is known to be enormous during the filling of the tanks. ${ }^{16-18} 24$ Younger deck officers in particular should take precautions during this procedure. A similarly high relative risk of kidney cancer (SIR after five years of employment $2.8,95 \%$ CI 1.6 to 4.7 ) reported earlier for Finnish oil refinery workers, ${ }^{25}$ was suggested to be attributable to the mixture of chemicals in the gasoline, which is also classified as possibly being carcinogenic for humans (group 2B) by the International Agency for Cancer Research. ${ }^{26}$

The OR of leukaemia was high and statistically significant for tanker personnel; it increased with years at work, strongly suggesting work related factors similar to those for kidney cancer. A similar but weaker trend was seen for lymphoma. It was not possible to find exact data about the contents of cargo or to analyse crude oil and chemical tankers separately. Seamen may be exposed to cargo vapours from gasoline and other light petroleum products on chemical or product tankers and-in lower concentrations-on crude oil tankers. ${ }^{16-18} 24$ It has been suggested that these exposures may be a possible reason for the increased incidence of lymphatic and haematopoetic malignancies among mates and able seamen on board ships of these types. ${ }^{6}$ The ORs for dry cargo ships were not increased for any cancers.

There are certain important potential confounders about which we did not have data, such as smoking habits and occupational exposures on shore. We attempted a postal inquiry to obtain answers to these issues, but it did not prove successful. The effect of general smoking prevalence on the ORs of lung cancer is crucial-causing, for example, the artefact that the work as a deck officer would be protective-but it hardly affects the increase of risk with increasing working years as seen among engine crew personnel. For mesothelioma, lymphoma, or leukaemia there are no such strong lifestyle related aetiological factors that could seriously bias our results.
In conclusion, this study indicates that work of deck crew on tankers involved exposure to occupational factors which add to their risk of kidney cancer, leukaemia, and possibly lymphoma. Engine crews evidently had an asbestos related risk of mesothelioma, and asbestos or other agents in the engine room air also seemed to increase their risk of lung cancer.

\section{ACKNOWLEDGEMENTS}

The authors would like to express their thanks to the Seafarers' Pension Fund and the National Board of Navigation for their kind help in finding information about seafarers and their work history. The support of The National Board of Antiquities of the Maritime Museum of Finland, the Finnish Shipowners' Association, Mrs Britta Enestam from Lloyd's Register of Shipping, Oy Rettig Ab BORE, Mr Thure Malmberg, and Mr Bengt Sjöström made it possible to identify the types of ships. The financial support of the Finnish Work Environment Fund is gratefully acknowledged.

\section{Authors' affiliations}

H Saarni, J Pentti, Finnish Institute of Occupational Health, Hämeenkatu 10, FIN-20500 Turku, Finland

E Pukkala, Finnish Cancer Registry, Liisankatu 21B, FIN-00170,

Helsinki, Finland

\section{REFERENCES}

1 Andersen A, Barlow L, Engeland A, et al. Work-related cancer in the Nordic countries. Scand J Work Environ Health 1999;25(suppl 2).

2 Plant MA. Occupational, drinking patterns and alcohol-related problems: conclusions from a follow-up study. Br J Addict 1974;74:267-73.

3 Tenfjord OW, Borchgrenvink CF, Vaa T, et al. Risikofaktorer for koronar hiertesykdom hos siömenn. Tidsskr Nor Laegeforen 1983:103:2312-16.

4 Saarni H, Niemi N. Working conditions of Finnish sea-pilots: health and work satisfaction. Part 1. Questionnaire study [in Finnish]. Report series of the Finnish Institute of Occupational Health in Turku 1989;4.

5 Laine M, Niemi L, Saarni H, et al. Health and working ability among Finnish seafarers [in Finnish]. Report series of the Finnish Institute of Occupational Health in Turku 1999;12.

6 Nilsson R. Cancer in seamen with special reference to chemical health hazards. Academic dissertation, University of Gothenburg, Gothenburg, Sweden, 1998.

7 Levin LI, Silverman DT, Hartge P, et al. Smoking patterns by occupation and duration of employment. Am J Ind Med 1990;17:71 1-25.

8 Blair A, Hoar SK, Walrath J. Comparison of crude and smoking-adjusted standardized mortality ratios. J Occup Med 1985;27:881-4.

9 Baksaas L, Lund E, Skjerven JE, et al. Cancer among merchant seamen. A cohort study [in Norwegian, with English summary]. Tidskr Nor Laegefore 1983;103:2317-20.

10 Selikoff IJ, Lilis R, Levin G. Asbestotic radiological abnormalities among United States merchant marine seamen. Br J Ind Med 1990;47:292-7.

11 Varouchakis G, Valonakis EG, Amfiochiou S, et al. Asbestos in strange places: two case reports of mesothelioma among merchant seamen. Am J Ind Med 1991;19:673-6. 
12 Greenberg $M$. Cancer mortality in merchant seamen. Ann N Y Acad Sci $1991 ; 643: 321-32$

13 Rafnsson V, Johannesdottir SG, Oddsson H, et al. Mortality and cancer incidence among marine engineers and machinists in Iceland. Scand J Work Environ Health 1988;14:197-200.

14 Dolin PJ, Cook-Mozaffari P. Occupation and bladder cancer: a death-certificate study. Br J Cancer 1992;66:568-78.

15 Nilsson RI, Carneskog J, Jarvholm BG, et al. Acute nonlymphatic leukemia among deck officers on coastal tankers: a report of two cases. Am J Ind Med 1988;14:657-9.

16 Moen BE, Hollund BE, Berntsen M, et al. Chemical exposure of deck crew on product tankers loading the cargo with the hatches open. Bull Inst Mar Trop Med Gdynia 1993/94;44/45:65-73.

17 Moen BE, Hollund BE, Berntsen $M$, et al. Exposure of the deck crew to carcinogenic agents on oil product tankers. Ann Occup Hyg 1995;39:347-61

18 Moen BE, Hollund BE, Berntsen M, et al. Occupational exposure of deck crews to carcinogenic agents on crude oil tankers. Am J Ind Med $1995 ; 27: 555-64$.
19 Pukkala E, Saarni H. Cancer incidence among Finnish seafarers. Cancer Causes Control 1996;7:231-9.

20 Spirtas R, Heineman EF, Bernstein L, et al. Malignant mesothelioma: attributable risk of asbestos exposure. Occup Environ Med 1994;51:804-11.

21 Gustavsson P. Cancer and ischemic heart disease in occupational groups exposed to combustion products. Arbete och Hälsa 1989:21.

2 Parkes WR. Occupational lung disorders. London: Butterworth-Heinemann, 1994.

23 Andrews KW, Savitz DA. Accuracy of industry and occupation on death certificates of electric utility workers: implications for epidemiologic studies of magnetic fields and cancer. Bioelectromagnetics 1999;20:512-28.

24 Nordlinder $\mathbf{R}$, Ramnäs $O$. Exposure to benzene at different work places in Sweden. Ann Occup Hyg 1987;31:345-55.

25 Pukkala E. Cancer incidence among Finnish oil refinery workers, 1971-1994. J Occup Environ Med 1998;40:675-9.

26 IARC. Occupational exposures in petroleum refining; crude oil and major petroleum fuels. IARC Monograph 45. Lyon: International Agency for Research on Cancer, 1989.

\section{Passive smoking may link asthma and social deprivation}

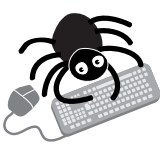

Please visit the Occupational and

Environmental Medicine website [www. occenvmed.com for link to this full article.
- xposure to environmental tobacco smoke may be a major cause of asthma attacks among disadvan— taged children. The findings of a large cross sectional study may explain the recognised association - of prevalence and severity of asthma with low income and deprivation and indicate a potential control measure.

Among 2986 Canadian schoolchildren with asthma studied, asthma attacks requiring an emergency hospital visit or overnight stay were significantly linked with family income. The mean frequency of hospital visits per year was $25 \%$ versus $16 \%$ for children of families with a yearly income of $<\$ 20000$ or $>\$ 60000$, respectively. Other significant factors were young age (5-12 years), lower parental education, unmarried parents, regular exposure to environmental tobacco smoke, and indicators of poor asthma control.

When compared across three bands of family income $(<\$ 20000, \$ 200000-\$ 60000$, and $>\$ 60000)$ each factor was associated with lower income. Multiple logistic regression showed that low income remained associated with hospital visits after adjusting for age, sex, and level of current asthma treatment but not after adjusting for parental education or exposure to environmental tobacco smoke.

The children were drawn from participants in a questionnaire survey of Canadian schoolchildren with asthma (Student Lung Heath Survey) who were aged 5-19 years with asthma previously diagnosed by a doctor. They or their parents provided information about family income (total household income before tax in the previous 12 months), hospital visits due to asthma (to the emergency department or entailing an overnight stay or longer in the same period), and other potential risk factors for asthma.

A Thorax 2002;57:513-517. 